\title{
Potential Uses of Curcumin and PMSG Hormones to Increase Egg Production of Muscovy Ducks through Increasing Estradiol Concentrations and Shortening Laying Rest Period
}

\author{
Dwi Gunadi ${ }^{1}$, Rukmiasih $^{2}$ and Wasmen Manalü* \\ ${ }^{1}$ Graduate School of Animal Production and Technology, Faculty of Animal Science, Bogor Agricultural University, \\ Dramaga Campus, 16680 Bogor, West Java Indonesia \\ ${ }^{2}$ Department of Animal Production and Technology, Faculty of Animal Science, Bogor Agricultural University, Dramaga \\ Campus, 16680 Bogor, West Java Indonesia \\ ${ }^{3}$ Department of Anatomy, Physiology, and Pharmacology, Faculty of Veterinary Medicine, Bogor Agricultural University, \\ Dramaga Campus, 16680 Bogor, West Java Indonesia \\ *Corresponding author email: wasmenmanalu@ymail.com
}

\begin{abstract}
The aim of this research was to study the effects of curcumin administration, injection of PMSG hormone, and the combination of curcumin supplementation and PMSG injection on the physiological parameters and performance of female Muscovy ducks. The objects of this research were 40 young female Muscovy ducks, aged 24 weeks, subjected to treatments: control (P1), curcumin supplementation at a dose of $24 \mathrm{mg} / 100 \mathrm{~g}$ feed (P2), intramuscular injection of PMSG hormone at a dose of $0.015 \mathrm{~mL} / \mathrm{hen}(\mathrm{P} 3)$, and the combination of curcumin and PMSG (P4). The results showed that the treatment gave nonsignificant improvements in Muscovy duck performances, including feed consumption, egg production, and the day of laying period and molting period. Treatment gave a significant increase in serum estradiol concentration at molting period after treatment. This study concluded that the treatment provides no significant improvement in the performance of female Muscovy ducks because the genetic diversity of Indonesian ducks remains high.
\end{abstract}

Keywords: Muscovy duck, curcumin, PMSG hormone, performance, physiological profile

\begin{abstract}
Abstrak. Penelitian bertujuan untuk mengkaji pemberian kurkumin melalui pakan, injeksi hormon PMSG, dan kombinasi suplementasi kurkumin dan injeksi PMSG pada parameter fisiologis dan performa entok betina. Objek dalam penelitian adalah entok betina dara umur 24 minggu sebanyak 40 ekor. Perlakuan yang diberikan dalam penelitian adalah kontrol tanpa perlakuan kurkumin dan PMSG (P1), pemberian kurkumin dengan level 24,0 mg/100 g pakan (P2), injeksi hormon PMSG dengan dosis 0,015 mL/ekor secara intramuskuler (P3), dan kombinasi pemberian kurkumin dan PMSG (P4). Hasil penelitian menunjukkan bahwa perlakuan memberikan perbaikan yang tidak nyata pada performa entok, yang meliputi konsumsi pakan, produksi telur, serta hari bertelur dan istirahat bertelur. Perlakuan memberikan peningkatan yang nyata pada konsentrasi estradiol serum pada saat istirahat bertelur setelah pemberian perlakuan. Kesimpulan penelitian ini adalah perlakuan memberikan perbaikan yang tidak nyata pada performa entok betina karena keragaman genetik entok Indonesia masih tinggi.
\end{abstract}

Kata Kunci: entok, kurkumin, hormon pmsg, performa, profil fisiologis

\section{Introduction}

Food security, especially animal protein, is an important concern. Indonesia's dependence on the overseas products for the supply of animal protein can actually be reduced and even eliminated. Poultry sector can be one of the keys to overcome this dependence. Poultry products are currently recognized as a more cost-effective way to supply the animal protein needs of people living in cities and towns (Pym, 2013). Indonesia has a very potential diversity of native and local poultry. However, native and local poultry have problems, including low population and productivity levels in producing eggs and meat, so they cannot meet the demand.

Indonesia is home to various types of poultry as the potential sources of meats and eggs. Both native and local poultry can anticipate the concerns that genetic variability in the strains of commercial poultry may vanish due to major disease outbreak due to a new strain. Muscovy duck is one of the local poultry having the 
potential as a source of meat. The production of Muscovy ducks is higher than that of other duck strains and duck meat flavour is not rancid, thus more preferred by consumers. The problem in Muscovy duck cultivation is the low productivity of eggs to produce day old ducks.

Efforts to improve the benefits of Muscovy ducks in eggs and meat production business need to be carried out by conducting a research through genetic and environmental pathways that optimize genetic potential of the local breeds. A study was conducted to shorten the length of incubation period associated with the hormone prolactin at the end of the laying period. Prolactin may act at all levels of the hypothalamo-hypophysial-gonadal axi s (HPG) and inhibit the function of reproduction.

Prolactin in poultry is involved in regulating gonad development and laying activity. This hormone suppresses the expression of aromatase induced by FSH and stimulates FSHinduced progesterone production in granulose cells, thus inhibiting the secretion of estradiol. The expression of prolactin in poultry promotes the early stages of follicular development, but suppresses follicle development in the next stage, so it has a dual role in poultry reproduction ( $\mathrm{Ma}$ et al., 2017). Efforts to suppress prolactin secretion can be done by increasing the concentrations of gonadotropin hormones.

Gonadotropin hormones can be increased by improving feed quality and quantity or injecting exogenous hormone. The potential feed ingredient in this study is curcumin because it has been extensively studied and widely known for its capacity to increase the productivity of livestock. Curcumin has a hepatoprotector activity which protects and prevents liver cells from damage, so it is expected to increase the biosynthetic capacity of hepatocytes to process and produce vitellogenin compound required for egg production. Supplementing curcumin as much as $36 \mathrm{mg} /$ hen/day combined with the use of monochromatic light can improve the biosynthetic capacity of hepatocytes to produce vitellogenin as a yolk protein precursor (Kasiyati et al., 2016).

Gonadotropin hormones can also be stimulated by injecting PMSG hormone because they have simultaneous activities of FSH and LH (Tagama, 2003). The presence of gonadotropin hormones will directly stimulate the synthesis and secretion of estradiol that eventually stimulates the synthesis of vitellogenin as eggyolk protein precursor. The synthesis of vitellogenin by the liver is highly dependent on estradiol stimulation. Estradiol stimulates the expression of mRNA precursors of egg yolk proteins, especially vitellogenin II and very lowdensity apolipoprotein II through estradiol receptors in poultry liver which will be carried through the blood circulation into the developing oocytes in the ovary (Li et al., 2014). The increased estradiol production by the developing follicles stimulated by gonadotropin hormone will also suppress the secretion of prolactin having a specific function to stimulate brooding behaviour.

Identifying the treatment effect will greatly support in increasing the productivity of Muscovy duck. Efforts to improve the productivity of Muscovy duck are important in order to provide a source of animal protein from livestock that is needed by the community. This study was conducted to evaluate the role of curcumin supplementation in feed and injection of the PMSG and their combinations in improving the productivity of Muscovy ducks. This technique can be applied by the farmers to increase the productivity of Muscovy duck to accomplish farmers' welfare and food sustainability, especially protein sources from livestock.

\section{Materials and Methods}

\section{Location and Time of Study}

The experiment was conducted from January to November 2020. Maintenance and 
performance analysis of Muscovy duck was carried out at the Field Laboratory of the Block B Poultry Unit and the Poultry Laboratory, Department of Animal Production and Technology, Faculty of Animal Science, Bogor Agricultural University. The physiological profile analysis of Muscovy duck was carried out at the Integrated Research Laboratory, Faculty of Veterinary Medicine, Syiah Kuala University, Banda Aceh.

\section{Experimental Design}

The study was conducted in a Completely Randomized Design (CRD). Forty young female Muscovy ducks aged 24 weeks and weighed 1.5 to $2.0 \mathrm{~kg}$ were obtained from the Poultry Production Division, Faculty of Animal Science, Bogor Agricultural University. Muscovy ducks were divided into four treatment groups (10 replicates) of the combined curcumin supplementation in feed and PMSG injection at the beginning of the second molting period. The treatment consisted of $\mathrm{P} 1=$ control without curcumin supplementation and PMSG injection, $\mathrm{P} 2=24 \mathrm{mg} / 100 \mathrm{~g}$ feed of curcumin supplementation in feed, P3 = injection of 0.015 $\mathrm{mL}$ PMSG hormone once intramuscularly in the breast, $\mathrm{P} 4=$ the combination of curcumin supplementation and PMSG injection.

\section{Experimental Procedure}

The experimental Muscovy ducks were maintained in individual cages with a size of 35 x $35 \times 29 \mathrm{~cm}$. Feeding and drinking water were provided ad libitum every day. The basal feed consisted of commercial feed for layer chicken with nutrient contents presented in Table 1. The main ingredients of the treatment were curcumin extract flour obtained from 95\% curcuminoid (Naturewise Organic Curcumin, USA) and PMSG hormone with the trademark Oocyte Development produced by Faculty of Fisheries and Marine Science, IPB University.

Performance measurements and analysis of experimental Muscovy ducks were carried out before and after the treatment. The performance analysis of Muscovy duck included feed consumption, egg production, egg abnormalities, as well as the length of laying and molting period.

The performances of experimental Muscovy ducks were measured in the 1st to 4th laying egg cycles. Feed consumption was observed at each phase of laying and molting period. Egg production and egg weight were recorded in detail. The length of the laying period was calculated from the first egg laying to the last egg laying in each cycle. The length of molting period was calculated from the time the Muscovy duck stops laying until the next eggs laying in each cycle. Observation of egg abnormalities was carried out by comparing egg weight and egg shell form with those of normal eggs, and the double yolk was identified using a candler.

Table 1. Nutritional contents of commercial layer feed

\begin{tabular}{ll}
\hline Nutrient & $\begin{array}{c}\text { Nutrient } \\
\text { contents }\end{array}$ \\
\hline Moisture (\%) & 13 \\
Crude protein (\%) & $17.5-19.5$ \\
Crude fat (\%) & 3 \\
Crude fiber (\%) & 7 \\
Ash (\%) & 14 \\
Calcium (\%) & $3.25-4.25$ \\
Phosphorus (\%) & 0.55 \\
Metabolizable energy & $2,725-2,825$ \\
(kcal/kg) & \\
\hline
\end{tabular}

\section{Blood Collection and Physiological Profile Analysis}

Physiological profile analysis was carried out by collecting blood serum from 3 broilers of each treatment. Blood samples were collected 3 times at 06.00-07.00 am. Samples were collected once before giving the treatment and twice post-treatment when the Muscovy duck laid eggs for the first time and at the end of the laying period. The blood samples were taken through the brachial vein using a $3 \mathrm{~mL}$ syringe on each wing. The individual serum formed was 
transferred into a microtube and stored at -20 ${ }^{\circ} \mathrm{C}$. Serum estradiol concentrations were measured by enzyme-linked immunosorbent assay (ELISA) method using the DGR EIA 2693 International Inc kit.

\section{Statistical Analysis}

The data obtained were then tested for normality and subjected to analysis of variance (ANOVA). Any significant difference $(P<0.05)$ from the result was analyzed for Honestly Significant Difference (HSD) to compare the difference between treatments. The results of the study were also tested by Pearson correlation analysis. Data analysis was conducted by using Statistical Analysis System 9.4 program.

\section{Results and Discussion}

\section{Feed Consumption}

Daily feed consumptions during the laying and molting period before and after treatment were not different. Daily feed consumption in the second laying period after treatment $\left(4^{\text {th }}\right.$ production phase) showed that the feed consumption of Muscovy duck that received treatment was higher than the control. Curcumin has a positive effect on increasing feed consumption because the bioactive substances can stimulate appetite and feed consumption, increase digestive enzyme secretion, activate immune system and antibacterial responses, and act as antioxidants (Nouzarian et al., 2011). The role of curcumin in poultry is related to vitellogenesis to help optimize the growth and development of egg follicles. Meanwhile, PMSG hormones with activities, such as gonadotropin hormones, can stimulate follicle growth and development. The growing follicles will increase the synthesis and secretion of estradiol and eventually stimulates and increases the duck's appetite. The plasma estradiol concentration increased with feed consumption (van der Klein et al., 2020). Daily feed consumption data are presented in Table 2.

The liver of laying poultry will work very hard to produce vitellogenin as a precursor of egg yolk. The increased biosynthetic activities of the liver during laying period make this organ susceptible to damage. Curcumin can provide protective and oxidative therapeutic effects on liver damage by suppressing proinflammatory cytokines and lipid peroxidation production, activating liver cells, and improving cellular responses to oxidative stress (Farzaei et al., 2018). Therefore, the experimental ducks that were given curcumin consumed more feed, presumably because they needed a lot of nutrients to maintain their health in addition to their requirements for egg productions.

Table 2. Average daily feed consumption

\begin{tabular}{|c|c|c|c|c|}
\hline \multirow{3}{*}{ Parameter } & \multicolumn{4}{|c|}{ Treatment } \\
\hline & P1 & $\mathrm{P} 2$ & P3 & P4 \\
\hline & ( $\mathrm{n}=9$ hens) & ( $n=10$ hens) & ( $n=10$ hens) & ( $n=9$ hens) \\
\hline \multicolumn{5}{|c|}{ Laying period (g/hen/day) } \\
\hline $1 *$ & $102.01 \pm 19.50$ & $116.25 \pm 13.97$ & $111.25 \pm 12.93$ & $113.98 \pm 18.75$ \\
\hline $2 *$ & $129.58 \pm 13.93$ & $125.30 \pm 22.66$ & $130.64 \pm 10.67$ & $124.58 \pm 14.79$ \\
\hline 3 & $129.87 \pm 5.67$ & $126.79 \pm 16.46$ & $131.33 \pm 14.10$ & $126.18 \pm 32.31$ \\
\hline 4 & $109.39 \pm 28.88^{b}$ & $133.85 \pm 8.44^{a}$ & $133.58 \pm 8.98^{\mathrm{a}}$ & $136.18 \pm 13.25^{\mathrm{a}}$ \\
\hline \multicolumn{5}{|c|}{ Laying rest period (g/hen/day) } \\
\hline $1 *$ & $83.07 \pm 18.00$ & $93.76 \pm 17.54$ & $98.07 \pm 22.07$ & $92.45 \pm 10.91$ \\
\hline 2 & $100.95 \pm 21.00$ & $107.29 \pm 15.72$ & $115.83 \pm 20.93$ & $102.03 \pm 22.00$ \\
\hline 3 & $99.10 \pm 20.67$ & $112.64 \pm 13.41$ & $107.12 \pm 14.78$ & $115.81 \pm 15.55$ \\
\hline 4 & $96.68 \pm 31.42$ & $113.06 \pm 15.73$ & $110.80 \pm 15.13$ & $110.64 \pm 20.05$ \\
\hline
\end{tabular}


Experimental ducks given or not given curcumin at molting period showed similar feed intakes. Similar results were reported by (Rahmani et al., 2017) that giving curcumin up to $400 \mathrm{mg} / \mathrm{kg}$ in feed did not affect broiler feed consumption. However, the daily feed consumptions of experimental ducks decreased at the first treatment, presumably because of the adaptation to the treatments. Poultry requires adaptations to feed and the environment by increasing the secretory activities of the digestive organs (Zaefarian et al., 2019). The treatment does not decrease the level of feed palatability, but it takes time to adapt to the treatment.

The daily feed consumption obtained was different from the results of (Baéza et al., 2017) who used various combinations of omega 3 and 6 fatty acids in female ducks to produce duckling obtained daily feed consumption ranging from 165-168 g/hen. Many factors influence feed consumption, both in terms of feed and management. Feed factors include the contents of energy, protein, amino acids, vitamins, minerals, and antinutrients in the ration, as well as consumption of drinking water. Management factors consist of easy access to feed and drinking water, environmental stress, disease, behaviour, and eating rhythm.

Factors that influence feed consumption are energy and protein contents of feed. There is an interaction effect between energy and protein in feed that can be metabolized by poultry in relation to their production capabilities (Zeng et al., 2015). It is recommended that feed for laying ducks contains $2,500 \mathrm{kcal} / \mathrm{kg}$ metabolic energy and $17 \%$ crude protein (Fouad et al., 2018). The feed given during the observation fulfilled these recommendations. Therefore, the nonsignificant different in feed consumption is probably the experimental ducks have fulfilled their needs for basic living and egg production.

There is a difference in daily feed consumption during the production and molting phases. During the egg production phase, the experimental ducks have higher daily feed consumption than during the resting phase. Ducks need a lot of nutrients to synthesize and form their eggs. Meanwhile, the molting Muscovy ducks lost appetites due to incubation behaviour so their daily feed consumptions decreased. The feed consumptions of control ducks in the 4th laying period were the lowest, followed by the low egg production. Curcumin supplementation and PMSG hormone injection resulted in an increased feed consumption followed by the improved quality and quantity of eggs produced.

Muscovy ducks still have broodiness behaviour causing a low daily feed intake and hence, limited nutrient intake for reproductive activities, especially egg formation. Egg production is related to follicular development which depends on reproductive conditions and feed nutrients consumed by poultry (Yoshida et al., 2011). Also, decreased feed consumption is due to molting at each laying cycle, which affects the behavior and body conditions of the experimental ducks. The increased feed intake of treated ducks during the molting phase is expected to accelerate the process of remodeling and repairing the reproductive organs for laying again.

\section{Egg Productivity}

The egg productions and egg weights of experimental Muscovy ducks after treatment were not different. Table 3 showed that the highest egg production (17.13 to 21.00 eggs) was found in the 1st laying period, with individual variations from 9 to 35 eggs. Egg production in the second laying period decreased by 5.84 to $33.86 \%$, with individual variations from 7 to 21 eggs. Egg production in the 3rd laying period (after treatment) increased compared to the 2nd period in P1 and P2 by 7.63 to $13.86 \%$, but decreased by 6.20 to $12.8 \%$ in P3 and P4 experimental ducks. Egg production during the 4th laying period 
increased by $5.50 \%$ in P3, but decreased by 9.09 to $16.52 \%$ in the other treatments.

The weights of eggs produced in the first laying period (before treatment) were 62.42 to $67.31 \mathrm{~g}$, with individual variations from 57.42 to $75.57 \mathrm{~g}$. In the production cycle of poultry, the hens will begin to lay eggs in small sizes, then within a matter of weeks, medium and large size (Iqbal et al., 2016). After the treatment, the experimental ducks produced 73.52 to $75.45 \mathrm{~g}$ eggs, with individual variations from 66.50 to $85.79 \mathrm{~g}$ during the 3rd laying period. Meanwhile, egg weight in the fourth laying period was 73.44 to $78.12 \mathrm{~g}$, with individual variations from 65.90 to $85.14 \mathrm{~g}$. Egg weight has increased with age and laying cycle.

The egg production in this study is not different from 7 to 19 eggs reported by Stai and Searcy (2010) on female Muscovy ducks for each clutch. The difference in egg production is attributed to many factors. In developing countries with hot tropical climates, the factors include managerial ability, availability of feed, competition with other livestock, extreme climate change, disease, and poor government policies affect poultry productivity (Oguntunji and Alabi, 2010). Environmental factors are the main non-genetic limiting factors on the expression of genetic potentials in poultry.

P4 ducks in the 3rd and 4th laying period produced the highest egg production, presumably because of the synergistic role between curcumin and PMSG hormone. Curcumin improves liver function so that the vitellogenesis synthesis to produce egg yolk precursors is more optimal, while the PMSG hormone will stimulate the egg formation process. Curcumin can increase metabolism, maximize vitellogenin synthesis, stimulate feed consumption, endogenous secretion, and poultry productivity (Park et al., 2012). Meanwhile, PMSG hormone has high effectiveness in stimulating superovulation because it has multiple actions, such as FSH and LH (Alvarez et al., 2016). P3 ducks during the 3rd laying period had the lowest egg production, presumably because the experimental ducks experienced physiological stress due to the first injection of PMSG.

The number and quality of eggs produced after treatment with curcumin supplementation and PMSG injection improved. The treatment did not have a negative effect on egg quality. This treatment produced 0.00 to 0.56 small eggs (<60 g), 1.22 to 8.00 large eggs ( $>80 \mathrm{~g}$ ), and 0.11 abnormal eggs, such as thin shells. Meanwhile, no double yolk egg was found. Therefore, the treatment can be used to improve the quality of eggs so that they are suitable for hatching.

Table 3. Number and average weight of eggs

\begin{tabular}{|c|c|c|c|c|}
\hline \multirow[b]{2}{*}{ Parameter } & \multicolumn{4}{|c|}{ Treatment } \\
\hline & $\begin{array}{c}P 1 \\
(n=9 \text { hens) }\end{array}$ & $\begin{array}{c}P 2 \\
(n=10 \text { hens })\end{array}$ & $\begin{array}{c}\text { P3 } \\
\text { ( } n=10 \text { hens) }\end{array}$ & $\begin{array}{c}P 4 \\
\text { ( } n=9 \text { hens) }\end{array}$ \\
\hline \multicolumn{5}{|c|}{ Number of eggs (eggs) } \\
\hline LP 1* & $17.33 \pm 8.08$ & $17.13 \pm 5.79$ & $21.00 \pm 8.09$ & $17.13 \pm 5.33$ \\
\hline LP 2* & $13.11 \pm 3.14$ & $12.63 \pm 4.78$ & $13.89 \pm 2.80$ & $16.13 \pm 2.64$ \\
\hline LP 3 & $14.11 \pm 5.33$ & $14.38 \pm 5.88$ & $12.11 \pm 5.13$ & $15.13 \pm 5.77$ \\
\hline LP 4 & $12.56 \pm 5.25$ & $12.00 \pm 3.74$ & $12.78 \pm 1.48$ & $13.75 \pm 2.19$ \\
\hline \multicolumn{5}{|c|}{ Average egg weight (g) } \\
\hline LP 1* & $65.72 \pm 3.74$ & $67.31 \pm 4.43$ & $67.23 \pm 4.05$ & $62.42 \pm 3.41$ \\
\hline LP 2* & $72.44 \pm 4.31$ & $71.30 \pm 6.65$ & $71.14 \pm 2.90$ & $71.27 \pm 4.02$ \\
\hline LP 3 & $74.01 \pm 2.32$ & $75.45 \pm 6.05$ & $73.52 \pm 3.45$ & $73.52 \pm 3.66$ \\
\hline LP 4 & $74.56 \pm 6.02$ & $78.12 \pm 4.35$ & $77.26 \pm 3.79$ & $73.44 \pm 3.87$ \\
\hline
\end{tabular}

$\mathrm{LP}=$ Laying period. The data shown are mean \pm standard deviation. $\left({ }^{*}\right)=$ pretreatment 
The improvement observed in the present study from biological and economical aspects had a positive effect on farmers because more Muscovy duck eggs could be hatched to produce day old duck (DOD).

\section{Lengths of Laying Period and Molting Period}

The treatment resulted in a nonsignificant improvement in the length of the laying period and molting period. The experimental ducks during egg production or laying period have non-laying days. There were a lot of non-laying days in the 1st laying period because the ducks were laying for the first time. The longer time required for egg formation, about 24-26 hours makes the possibility of non-laying days. Egg production in poultry is almost daily with a biological limit of one egg per day, but there are times when birds do not produce eggs because ovulation occurs on the next day (Bain et al., 2016). The non-laying days after the experimental ducks were treated with curcumin supplementation and PMSG injection (LP3) ranged from 2.00 to 5.22 days. The experimental ducks are expected to have a low number of non-laying days so that the percentage of eggs produced during the laying period is high.

The length of molting period after the 1st laying period ranged from 22.33 to 55.75 days, with individual variations from 6 to 143 days. Experimental ducks at the beginning of the second molting period were treated with curcumin supplementation and PMSG injection and produce molting period ranging from 25.00 to 46.75 days, with individual variations of 9 to 124 days. At the individual level, ducks experienced a reduction in molting period by 1 30 days at $77.78 \%$ of $\mathrm{P} 1$ ducks, 4-7 days at $28.57 \%$ of $\mathrm{P} 2$ ducks, $7-36$ days at $33.33 \%$ of $\mathrm{P} 3$ ducks, and $2-108$ days at $75.00 \%$ of $\mathrm{P} 4$ ducks. The days of the 3rd molting period varies from 29.63 to 33.13 days, with individual variations from 7 to 65 days. At the individual level, the response of experimental ducks experienced a reduction in molting period with the details of 2-64 days at $55.56 \%$ of P1 ducks, 2-115 days at $57.14 \%$ of $P 2$ ducks, $2-24$ days at $44.44 \%$ of $P 3$ ducks, and $2-6$ days at $50.00 \%$ of P4 ducks. The length of laying period and molting period are presented in Table 4.

The second molting period was prolonged, presumably due to the adaptation period to the treatment of curcumin and PMSG hormone separately. The experimental ducks that were stressed after being given the treatment caused the process of egg formation to be disturbed, thus extending the resting time. Endocrine response to stress is characterized by the increased secretion of glucocorticoids regulated

Table 4. Length of laying period and molting period

\begin{tabular}{|c|c|c|c|c|}
\hline \multirow[b]{2}{*}{ Parameter } & \multicolumn{4}{|c|}{ Treatment } \\
\hline & $\begin{array}{c}P 1 \\
\text { ( } n=9 \text { hens) }\end{array}$ & $\begin{array}{c}\text { P2 } \\
\text { ( } n=10 \text { hens) }\end{array}$ & $\begin{array}{c}P 3 \\
\text { ( } n=10 \text { hens) }\end{array}$ & $\begin{array}{c}\text { P4 } \\
\text { ( } n=9 \text { hens) }\end{array}$ \\
\hline \multicolumn{5}{|c|}{ Length of laying period (days) } \\
\hline $1 *$ & $20.11 \pm 9.09$ & $22.13 \pm 5.19$ & $26.00 \pm 10.12$ & $21.25 \pm 7.29$ \\
\hline $2^{*}$ & $14.44 \pm 3.17$ & $14.00 \pm 4.60$ & $15.22 \pm 3.11$ & $18.13 \pm 2.75$ \\
\hline 3 & $18.00 \pm 7.78$ & $17.00 \pm 6.74$ & $14.22 \pm 5.89$ & $18.63 \pm 7.65$ \\
\hline 4 & $16.11 \pm 6.88$ & $15.00 \pm 4.04$ & $14.67 \pm 2.50$ & $15.75 \pm 2.05$ \\
\hline \multicolumn{5}{|c|}{ Length of molting period (days) } \\
\hline $1^{*}$ & $44.22 \pm 23.25$ & $28.63 \pm 22.08$ & $22.33 \pm 17.68$ & $55.75 \pm 47.86$ \\
\hline 2 & $36.56 \pm 19.14$ & $46.75 \pm 35.96$ & $25.00 \pm 9.80$ & $27.38 \pm 14.98$ \\
\hline 3 & $32.89 \pm 21.01$ & $33.13 \pm 15.88$ & $30.00 \pm 20.34$ & $29.63 \pm 19.63$ \\
\hline $4^{* *}$ & $41.00 \pm 29.51$ & $15.00 \pm 1.41$ & $29.43 \pm 19.54$ & $10.67 \pm 3.06$ \\
\hline
\end{tabular}

The data shown are mean \pm standard deviation. $\left({ }^{*}\right)=$ pretreatment. $\left({ }^{* *}\right)$ The number of $\mathrm{P} 1=3$ hens, $\mathrm{P} 2=3$ hens, P3 $=7$ hens, $\mathrm{P} 4=4$ hens. 
by the hypothalamic-pituitary-adrenal axis (HPA) which gives a signal to the HPG axis, thus affecting egg production (Wang et al., 2017). The response of experimental ducks to treatment occurs naturally because the body will respond to the objects that are considered foreign when they first enter the body.

Experimental ducks that enter their molting period generally experience the actual molting. Histological analysis of tissue regression and regeneration of reproductive organs in poultry during molting includes a drastic change in size resulting in involution and formation of tubular glands (Jeong et al., 2013). Epithelial cells will degenerate and there will be a decrease in secretion in the gland, followed by a gradual regeneration of the oviduct. The shortened days of molting period is thought to be due to the influence of curcumin and the PMSG hormone which can help accelerate the regeneration process of the reproductive tracts of Muscovy ducks.

Curcumin helps optimize the performance of the reproductive organs, while the PMSG hormone stimulates the egg formation process. Curcumin not only protects cells but also promote the autophage process (mitophage) and repair mitochondrial damage and dysfunction caused by oxidative stress (Sala de Oyanguren et al., 2020). Meanwhile, superovulation is induced by PMSG hormone although it can increase the secretion of gonadotropin hormone, but will affect the parent environment because it causes the excessive oxidative stress by increasing the expression of 2-Cys peroxiredoxins in the female reproductive organs (Park et al., 2015). Therefore, follicular atresia was still found in P3 ducks when the ovarian morphology was observed.

The days of molting period relates to the brooding phase after the ducks stop laying. Muscovy ducks still have a strong broodiness even though they are bathed and their eggs were collected every day. The brooding nature appears due to a low egg production of Muscovy duck. The ability to incubate can inhibit egg production because the ruptured follicles stimulate granulose cells to synthesize progesterone which causes the inhibition of ovulation so the functions of ovaries and oviducts decline (Clark, 2019). The low egg production of Muscovy duck is due to the complex interactions between the feed, the endocrine system, the physiological functions of the organs, and the mechanisms involved in the egg production process.

\section{Serum Estradiol Concentrations}

Serum estradiol concentrations of experimental ducks did not differ at the molting period before treatment. The estradiol concentrations obtained ranged from 0.06 to $0.13 \mathrm{ng} / \mathrm{mL}$, with individual variations from 0.04 to $0.17 \mathrm{ng} / \mathrm{mL}$. The results showed that the optimization use of estradiol was not significant during the 3rd laying period (LP3). Estradiol concentrations obtained ranged from 0.44 to $0.55 \mathrm{ng} / \mathrm{mL}$, with individual variations from 0.20 to $0.87 \mathrm{ng} / \mathrm{mL}$. However, the treatment significantly increased serum estradiol concentrations during the 3rd molting period $(P<0.05)$. Serum estradiol concentrations during this phase ranged from 0.05 to $0.13 \mathrm{ng} / \mathrm{mL}$, with individual variations from 0.04 to $0.17 \mathrm{ng} / \mathrm{mL}$. The serum estradiol concentration during laying period and molting period are presented in Figure 1.

The estradiol has a function to stimulate the synthesis of vitellogenin by the hepatocytes as a precursor of egg yolk formation. Concentrations of estradiol in the blood decreased during egg production period due to the increased uptake of estradiol by the hepatocytes. A large amount of egg yolk proteins, such as apolipoprotein II and vitellogenin during egg production period, were synthesized in the liver under the stimulation of estradiol (Ratna et al., 2016). 


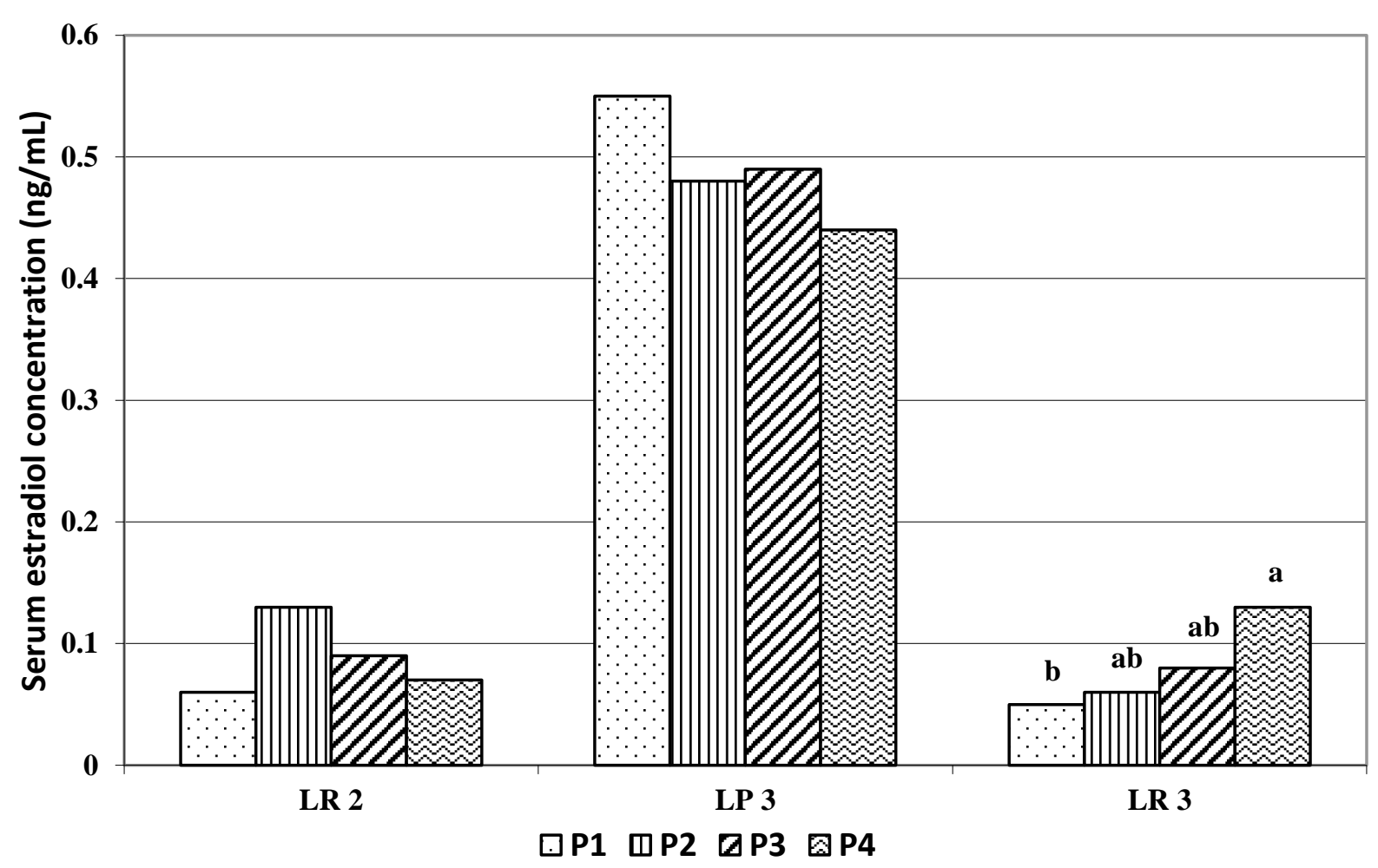

Figure 1. The profiles of the serum estradiol concentrations $(\mathrm{ng} / \mathrm{mL})$ were observed before and after treatment. LR 2 = 2nd molting period. LP $3=3$ rd laying period. LR $3=3$ rd molting period. Different superscripts mean significant difference $(P<0.05) . n=3$ for each treatment.

The change in reproductive activity from laying to brooding is the result of a complex process of neuroendocrine regulating the regressions of ovaries and oviducts (Ye et al., 2019).

The high concentrations of serum estradiol in P2 experimental ducks at the 2 nd molting period and 3rd laying period were thought to be the stimulation of higher vitellogenin synthesis for the production of large eggs. Curcumin is thought to help improve the quality of the eggs produced. Experimental ducks supplemented with curcumin and injected with PMSG had a higher estradiol concentrations compared to controls ducks. Curcumin has a potential gonadal protective effect because it is able to modulate estrogen, while the PMSG hormone is one of the triggers for increasing estradiol levels apart from the effect of curcumin.

The concentrations of estradiol at the 3rd molting period increased significantly. The increased estradiol concentrations during molting period probably contributed by the developing follicle. The main source of estradiol in poultry is theca cells surrounding the follicles in the ovary, where estradiol is very important for gonad differentiation and development, reproductive behavior, albumen protein synthesis in the oviduct, yolk protein synthesis in the liver, and calcium mobilization for eggshell formation (Liu et al., 2015). Therefore, high estradiol concentrations during the resting phase causes the next laying period in the treatment ducks were achieved faster than the control ducks.

Estradiol concentrations during the 2nd molting period had a negative correlation with estradiol levels in the 3rd laying phase $(-0.615)$, but positively correlated with vitellogenin concentrations (0.616). Estradiol concentrations during the 3rd laying period had a positive correlation with egg production and laying days in the 4th laying period, which were 0.668 and 0.641 , respectively. Serum estradiol concentrations during the 3rd molting period 
were negatively correlated with the number of large eggs during maintenance (-0.665). Meanwhile, a positive correlation was found with the number of small eggs during maintenance (0.633).

\section{Conclusions}

The supplementation of curcumin and PMSG hormone provides no significant improvement in the performance of female Muscovy ducks because the genetic diversity of Indonesian ducks remains high. However, curcumin and PMSG hormone potentially improve the performance of Muscovy ducks.

\section{Acknowledgement}

This research is accomplished with support and funding of the Indonesia Endowment Fund for Education (LPDP RI) under the responsibility of the Ministry of Finance of the Republic of Indonesia.

\section{References}

Alvarez, RH, FLN Natal, MTCP Ribela, BEde Almeida, JE de Oliveira, and $P$ Bartolini. 2016. Physicalchemical and biological characterization of different preparations of equine chorionic gonadotropin. Journal of Veterinary Science. 17(4): 459-465.

Baéza, E, P Chartrin, T Bordeau, M Lessire, JM Thoby, $\checkmark$ Gigaud, M Blanchet, A Alinier and C Leterrier. 2017. Omega-3 polyunsaturated fatty acids provided during embryonic development improve the growth performance and welfare of Muscovy ducks (Cairina moschata). Poult Sci. 96(9): 3176-3187.

Bain, MM, Y Nys and IC Dunn. 2016. Increasing persistency in lay and stabilising egg quality in longer laying cycles. What are the challenges?. $\mathrm{Br}$ Poult Sci. 57(3): 330-338.

Clark, MI. 2019. Management of breeding in small. In: veterinary reproduction and obstetrics. 10th ed. Noakes DE, TJ Parkinson and GCW England (Eds). Saunders Ltd., Philadelphia. Pp. 526-540.

Farzaei, MH, M Zobeiri, F Parvizi, FF El-Senduny, I Marmouzi, E Coy-Barrera, R Naseri, SM Nabavi, R Rahimi, and M Abdollahi. 2018. Curcumin in liver diseases: A systematic review of the cellular mechanisms of oxidative stress and clinical perspective. Nutrients. 10(7): 1-28.
Fouad, AM, D Ruan, S Wang, W Chen, W Xia, and C Zheng. 2018. Nutritional requirements of meattype and egg-type ducks: What do we know?. J Anim Sci Biotechnol. 9(1): 1-11.

Iqbal, J, SH Khan, N Mukhtar, T Ahmed, and RA Pasha. 2016. Effects of egg size (weight) and age on hatching performance and chick quality of broiler breeder. J Appl Anim Res. 44(1):54-64.

Jeong, W, W Lim, SE Ahn, CH Lim, JY Lee, SM Bae, J Kim, FW Bazer and G Song. 2013. Recrudescence mechanisms and gene expression profile of the reproductive tracts from chickens during the molting period. PLoS One. 8(10): e76784.

Kasiyati, Sumiati, DR Ekastuti and W Manalu. 2016. Roles of curcumin and monochromatic light in optimizing liver function to support egg yolk biosynthesis in magelang ducks. Int J Poult Sci. 15(10): 414-424.

Li, J, IH Leghari, B He, W Zeng, Y Mi, and C Zhang. 2014. Estrogen stimulates expression of chicken hepatic vitellogenin ii and very low-density apolipoprotein ii through er- $\alpha$. Theriogenology. 82(3): 517-524.

Liu, L, D Li, E R Gilbert, Q Xiao, X Zhao, Y Wang, H Yin and $Q$ Zhu. 2015. Effect of monochromatic light on expression of estrogen receptor (er) and progesterone receptor (pr) in ovarian follicles of chicken. PLoS One. 10(12): e0144102.

Ma, L, K Sun, K Tu, L Pan and W Zhang. 2017. Identification of double-yolked duck egg using computer vision. PLoS One. 12(12): e0190054.

Nouzarian, R, SA Tabeidian, M Toghyani, G Ghalamkari, and M Toghyani. 2011. Effect of turmeric powder on performance, carcass traits, humoral immune responses, and serum metabolites in broiler chickens. J Anim Feed Sci. 20(3): 389-400.

Oguntunji, AO, and OM Alabi. 2010. Influence of high environmental temperature on egg production and shell quality: A review. Worlds Poult Sci J. 66(4): 739-750.

Park, SS, JM Kim, EJ Kim, HS Kim, BK An and CW Kang. 2012. Effects of dietary turmeric powder on laying performance and egg qualities in laying hens. Korean J Poult Sci. 39(1): 27-32.

Park, SJ, TS Kim, JM Kim, KT Chang, HS Lee and DS Lee. 2015. Repeated superovulation via $\mathrm{pmsg} / \mathrm{hcg}$ administration induces 2-cys peroxiredoxins expression and overoxidation in the reproductive tracts of female mice. Mol Cells. 38(12): 1071-1078.

Pym, R. 2013. Poultry Development: Contribution of indigenous genotypes to production and consumption of poultry meat and eggs. Food and Agriculture Organization. Pp. 84-85.

Rahmani, M, A Golian, H Kermanshahi, and MR Bassami. 2017. Effects of curcumin and 
nanocurcumin on growth performance, blood gas indices and ascites mortalities of broiler chickens reared under normal and cold stress conditions. Ital J Anim Sci. 16(3): 438-446.

Ratna, WN, VD Bhatt, K Chaudhary, AB Ariff, SA Bavadekar and HN Ratna. 2016. Estrogenresponsive genes encoding egg yolk proteins vitellogenin and apolipoprotein ii in chicken are differentially regulated by selective estrogen receptor modulators. Theriogenology. 85(3): 376-383.

Sala, de OFJ, NE Rainey, A Moustapha, A Saric, F Sureau, JE O'Connor, and PX Petit. 2020. Highlighting curcumin-induced crosstalk between autophagy and apoptosis as supported by its specific subcellular localization. Cells. 9(2): 361.

Stai, SM, and WA Searcy. 2010. Passive sperm loss and patterns of sperm precedence in Muscovy ducks (Cairina moschata). Auk. 127(3): 495-502.

Tagama, TR. 2003. Reproduction performance of local cock (Gallus domesticus) primary organ with gonadotrophin hormone induction. Anim. Prod. 5 (2): 87-92.

Van, der KSAS, MJ Zuidhof, and GY Bédécarrats. 2020. Diurnal and seasonal dynamics affecting egg production in meat chickens: A review of mechanisms associated with reproductive dysregulation. Anim Reprod Sci. 213(2020): 106257.

Wang, XJ, L Liu, JP Zhao, HC Jiao, and H Lin. 2017. Stress impairs the reproduction of laying hens: An involvement of energy. Worlds Poult Sci J. 73(4): 845-856.

Ye, P, K Ge, M Li, L Yang, S Jin, C Zhang, X Chen and Z Geng. 2019. Egg-laying and brooding stagespecific hormonal response and transcriptional regulation in pituitary of Muscovy duck (Cairina moschata). Poult Sci. 98(11):5287-5296.

Yoshida, N, M Fujita, M Nakahara, T Kuwahara, SI Kawakami, and T. Bungo. 2011. Effect of high environmental temperature on egg production, serum lipoproteins and follicle steroid hormones in laying hens. J Poult Sci. 48(3):207-211.

Zaefarian, F, MR Abdollahi, A Cowieson, and V Ravindran. 2019. Avian liver: The forgotten organ. Animals. 9(2):1-23.

Zeng, Q, P Cherry, A Doster, R Murdoch, O Adeola, and T J Applegate. 2015. Effects of dietary energy and protein content and lipid source on growth performance and carcass traits in pekin ducks. Poult Sci. 94(3): 384-394. 